\title{
SEASONAL VARIATION IN OFFSPRING SEX RATIO IN THE SNOWY PLOVER
}

\author{
Sarah T. Saalfeld 1,4 , Warren C. Conway ${ }^{1}$, David A. Haukos ${ }^{2,5}$, and William P. Johnson ${ }^{3,6}$
}

\begin{abstract}
Aвstract.-The Snowy Plover (Charadrius nivosus) is unique in being a determinate layer of an odd modal clutch size and in having a variable mating system in which female brood desertion occurs regularly. These traits make determining Snowy Plover offspring sex ratios important not only for long-term population stability, as the species is of conservation concern, but also for application to sex allocation theory. In this study, we determined Snowy Plover offspring sex ratios, examined differential costs of producing male and female offspring, and evaluated sex ratio variation in relation to maternal condition, habitat condition, and time during the nesting season on saline lakes of the Southern High Plains of Texas. Examination of 245 chicks from 118 clutches during 1999-2000 and 2008-2009 showed that male offspring were more costly to produce than female offspring; however, offspring sex ratio did not differ from parity, but was slightly male-biased in most years. The probability of producing a male offspring was greater both earlier and later in the breeding season than in the middle. As the availability of saline lake surface water and the subsequent availability of food vary unpredictably throughout the breeding season, depending on precipitation events, we suggest that sex ratio adjustment in unpredictable environments may not be straightforward and may follow nonlinear models and/or vary annually. The effects such changes in sex ratios may have on population growth and stability remain unknown.
\end{abstract}

RESUMEN.-El chorlitejo blanco (Charadrius nivosus) es único en producir una cantidad fija impar de huevos y en tener un sistema de apareamiento variable en el cual la hembra abandona la puesta de manera regular. Por estos motivos es muy importante determinar la proporción sexual de las crías del chorlitejo blanco, no sólo por la estabilidad de la población a largo plazo, ya que se busca conservar la especie, sino porque se relaciona con la teoría de asignación de sexos. En este estudio, examinamos la proporción de sexos de las crías del chorlitejo blanco, examinamos los costos diferenciales de producir machos y hembras y evaluamos la variación en la proporción sexual en relación con la condición de la madre, del hábitat y el tiempo durante la época de anidación en lagos salinos de Southern High Plains en Texas. De un grupo de 245 pollos provenientes de 118 puestas durante 1999-2000 y 2008-2009, observamos que fue más costoso producir crías machos; sin embargo, la proporción de sexos no fue distinta de la paridad, aunque se inclinó ligeramente hacia los machos en la mayoría de los años. La probabilidad de producir machos fue superior tanto en las fases tempranas como en las fases tardías de la época de reproducción en comparación con las fases intermedias. Como la disponibilidad de agua del lago salino y la consecuente disponibilidad de alimento, varían de manera impredecible a lo largo de la época de reproducción, según las precipitaciones, sugerimos que los ajustes de la proporción sexual en ambientes impredecibles pueden no ser directos, siguiendo modelos no lineales y/o variando cada año. No se conocen los efectos de tales cambios en la proporción de sexos sobre el crecimiento y la estabilidad de la población.

Fisher (1930) predicted that when costs of producing male and female offspring are equal, offspring sex ratio should not differ from parity. However, if one sex is more costly to produce, excess individuals of the less costly sex would be expected. Additionally, females may enhance lifetime fitness by producing the sex with the greatest potential reproductive value (Trivers and Willard 1973). Until relatively recently, accurate sexing of monomorphic birds, particularly juveniles (i.e., hatching to fledging), has been nearly impossible. However, advancements in molecular sexing techniques (Ellegren and Sheldon 1997, Griffiths et al. 1998) allow for accurate sex determination of birds and eggs, resulting in a vast increase in studies investigating sex ratio manipulation (see Alonso-Alvarez 2006). In birds, offspring sex ratios rarely differ from parity (CluttonBrock 1986), but deviations have been correlated with environmental, conditional, and social factors for a number of avian species (see Gowaty 1993, Pike and Petrie 2003). Some factors potentially influencing offspring sex

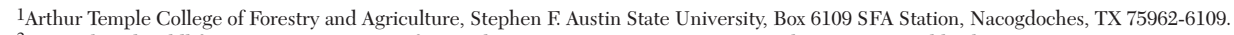

${ }^{2}$ U.S. Fish and Wildlife Service, Department of Natural Resources Management, Texas Tech University, Lubbock, TX 79409-2125.

${ }^{3}$ Texas Parks and Wildlife Department, Box 659, Canyon, TX 79015.

4 Present address: Manomet Center for Conservation Sciences, U.S. Fish and Wildlife Service, 1011 East Tudor Road, MS 201 , Anchorage, AK 99503. E-mail: saalfeldst@gmail.com

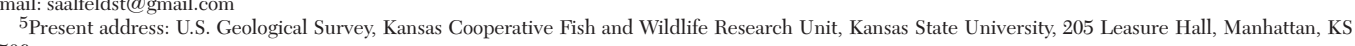
66506 .

${ }^{6}$ Present address: U.S. Fish and Wildlife Service, National Wildlife Refuge System, Division of Biological Sciences, Box 60906, West Texas A\&M University, Canyon, TX 79016
} 
ratios include maternal condition (Nager et al. 1999, Korpimäki et al. 2000), parental age (Blank and Nolan 1983, Cooch et al. 1997), mate attractiveness (Burley 1981, Ellegren et al. 1996, Sheldon et al. 1999), laying/hatching date (Howe 1977, Dijkstra et al. 1990, Zijlstra et al. 1992, Daan et al. 1996, Smallwood and Smallwood 1998, Székely et al. 2004), and laying/hatching sequence (Ankney 1982, Bednarz and Hayden 1991). Despite widespread associations between these factors and sex ratios, no mechanism causing skewed sex ratios in birds has been identified (Krackow 1995, Pike and Petrie 2003, Alonso-Alvarez 2006).

Female condition is suspected to influence offspring sex ratios, as females in poor condition may not be able to withstand the physiological stress of producing the more costly sex (Myers 1978). In many avian species (excluding those with reverse sexual dimorphism), females are generally considered to be the less expensive sex, as female offspring typically require less maternal investment due to their smaller egg size and slower growth rates (Mead et al. 1987). Therefore, females in poor condition may produce more daughters than sons, as daughters can be successfully produced even when the female is in poor condition. Additionally, Trivers and Willard (1973) proposed that for species in which differential advantages benefit males more than females (e.g., polygynous species, species that exhibit male resource/territory defense, and male competition for mates), females in good condition may attain greater lifetime fitness by producing sons. Conversely, females in poor condition may attain greater lifetime fitness by producing more daughters than sons, as female offspring require less maternal investment and will likely attain some lifelong fitness, regardless of maternal condition. Male offspring of poor quality would likely not develop the physical characteristics necessary to compete successfully for females, furthering the notion that females in poor condition should at least produce daughters (Trivers and Willard 1973). The Trivers and Willard hypothesis assumes that offspring condition is correlated with female condition, that the condition of the young will carry over to adulthood, and that conditional advantages will differentially benefit male offspring in reproductive success (Trivers and Willard 1973). Maternal condition, however, may vary with habitat conditions and prey availability, such that poor habitat conditions and associated poor female condition may result in female-biased offspring sex ratios (Howe 1977, Myers 1978, Wiebe and Bortolotti 1992, Korpimäki et al. 2000).

Laying/hatching date may also influence the offspring sex ratio, with many avian taxa exhibiting seasonal variation in sex ratios, including shorebirds (Andersson et al. 2003, Székely et al. 2004), raptors (Dijkstra et al. 1990, Olsen and Cockburn 1991, Tella et al. 1996, Smallwood and Smallwood 1998, Pen et al. 1999, Korpimäki et al. 2000, Byholm et al. 2002, Griggio et al. 2002), and passerines (Cordero et al. 2001, McIntosh et al. 2003). Most studies have reported male-biased sex ratios for broods hatching earlier in the season and female-biased sex ratios for those hatching later in the season (Dijkstra et al. 1990, Tella et al. 1996, Smallwood and Smallwood 1998, Korpimäki et al. 2000, Byholm et al. 2002, Griggio et al. 2002, Andersson et al. 2003, Székely et al. 2004). Theoretically, males born earlier have a developmental and fitness-based advantage (either born during times of greater food availability or having longer to obtain food) over those born later. Males born earlier are more likely to find and defend territories, successfully compete for mates, and breed within their first year (Trivers and Willard 1973, Daan et al. 1996). The developmental advantages of hatching early may be less important for females, as females are likely to breed regardless of condition (Trivers and Willard 1973, Daan et al. 1996). Conversely, in species with alternate breeding strategies (e.g., females that defend resources and compete for mates and/or do not breed within their first year), female-biased sex ratios were observed earlier in the season (Howe 1977, Olsen and Cockburn 1991, Zijlstra et al. 1992, Daan et al. 1996, Cordero et al. 2001, McIntosh et al. 2003). Here, females were hypothesized to have a reproductive advantage over males, as females born earlier were more likely to find suitable breeding locations, find and defend territories, and/or compete for mates. Mothers may accrue fitness benefits by varying the offspring sex ratios according to hatching date, favoring early hatching dates for the sex that gains greatest advantages by hatching earlier.

Snowy Plovers (Charadrius nivosus) are unique in being a determinate layer of an odd modal clutch size of 3 eggs and having a variable 
mating system. These characteristics make this species particularly interesting for the study of sex allocation. For example, production of an odd modal clutch size forces individuals to invest differentially in a particular offspring sex. Although the genetic mating system of the closely related Kentish Plover (Charadrius alexandrinus) is predominantly monogamous (Küpper et al. 2004), the social mating system of both Snowy and Kentish Plovers varies within and among populations and has been described as facultatively polygynous, monogamous, and polyandrous (Page et al. 2009), with both parents capable of initiating second nesting attempts (Boyd 1972, Lessells 1984, Warriner et al. 1986, Székely and Lessells 1993, Székely and Williams 1994, 1995, Amat et al. 1999, Stenzel et al. 2011). However, females typically renest at greater rates than males, as males are typically the care-giving parent during brood rearing (Lessells 1984, Warriner et al. 1986, Székely and Lessells 1993, Székely and Cuthill 1999, 2000, Székely et al. 1999, Stenzel et al. 2011). This mating system is possible only if individuals are able to find and acquire a new mate after their first nesting attempt. Sex-biased mating opportunities may be facilitated by biased adult sex ratios (either due to biased offspring sex ratios or sex-biased survival rates) or different breeding schedules (e.g., males breed longer each year or for more years than females; Székely et al. 2004).

Snowy Plover populations have declined throughout their range in the United States and are currently listed as threatened by the U.S. Fish and Wildlife Service along the Pacific Coast (USFWS 1993) and as endangered, threatened, or of special concern in several states (see Page et al. 2009). Within the Southern High Plains (SHP) of Texas, a 78\% regional population decline has been documented on an important saline lake since the late 1990s (Saalfeld et al. 2013). Saline lakes within the SHP are of continental importance to nesting Snowy Plovers, as a large proportion of the interior population nest within, as well as migrate through, this region (Conway 2001, Conway et al. 2005a). However, habitat quality of saline lakes has declined, making many of them unsuitable for migrating (Andrei et al. 2008) and nesting shorebirds. In species with low reproductive rates (i.e., few offspring produced per female) and relatively high adult survivorship, sex ratios can have important implications for long-term population stability. Therefore, examining sex ratios and sex allocation theory can provide insight into potential limitations of population growth as well as provide data for population demographic models. The objectives of this study were to (1) document offspring sex ratios of Snowy Plovers in the SHP of Texas, (2) determine potential costs (i.e., hatchling and egg sizes) of producing offspring of different sexes, and (3) evaluate sex ratio adjustments based on maternal condition, habitat, and hatching date.

\section{Methods}

\section{Study Area}

The SHP is a region of approximately $80,000 \mathrm{~km}^{2}$ in the western Texas Panhandle, south to Midland, Texas, and into New Mexico (Osterkamp and Wood 1987). Within this region, there are approximately 40 saline lakes (Reeves and Temple 1986), which comprise the primary regional nesting location for Snowy Plovers (Conway et al. 2005a). Saline lakes are discharge wetlands containing freshwater springs fed by the Ogallala aquifer (Brune 2002) but having an overall saline water chemistry (often $>200 \mathrm{~g} \cdot \mathrm{L}^{-1}$ of dissolved solids; Osterkamp and Wood 1987). We used as study sites in 1999-2000 and 2008-2009 three saline lakes ranging in size from approximately 270 ha to $600 \mathrm{ha}$. These lakes have been previously identified as important to Snowy Plovers (i.e., having consistent surface water throughout the nesting season and containing the majority of regional nesting Snowy Plovers; Conway et al. 2005a). To maintain landowner anonymity, we refer to the study site lakes as lake A, lake B, and lake C. Each study site lake contained 2-6 fresh to slightly saline springs distributed along lake margins (Brune 2002). Pasture/grassland, including some held within the U.S. Department of Agriculture Conservation Reserve Program, was the primary land-use practice immediately surrounding the study site lakes. Other land-use practices occurring within surrounding areas included row-crop agriculture production (i.e., mostly cotton [Gossypium spp.]), mineral excavation (e.g., caliche), and development (i.e., mostly small home/ranch developments).

Weather conditions were variable among years. In 2008 and 2009, drought conditions were present. From January to July in 2008 
and 2009, cumulative rainfall in the city of Tahoka (Lynn County, TX), the closest city to all 3 study site lakes $(<40 \mathrm{~km})$, was estimated at $10.5 \mathrm{~cm}$ and $19.9 \mathrm{~cm}$ below the long-term average, respectively (National Climate Data Center; http://cdo.ncdc.noaa. gov). Conversely, in 1999 and 2000, wet conditions were present, with a cumulative rainfall in the city of Tahoka from January to July in 1999 and 2000 estimated at $7.1 \mathrm{~cm}$ and $9.0 \mathrm{~cm}$ above the long-term average, respectively (National Climate Data Center; http://cdo.ncdc.noaa. gov). Among years, however, average temperatures tended to be similar, ranging from -3.3 to 42.2 ${ }^{\circ} \mathrm{C}$ from April to July (National Climate Data Center; http://cdo.ncdc.noaa. gov).

\section{Nest Surveys}

We conducted surveys $\geq 1$ time per week at each lake during the breeding season (i.e., early April-mid August; Conway et al. 2005a) in 1999-2000 and 2008-2009 to locate new nests. We located nests by searching appropriate habitat and by observing adult Snowy Plovers incubating at, flushing from, or returning to nests (Conway et al. 2005a). For nests discovered in 2008 and 2009, we recorded the primary nest substrate (i.e., sand or pebble) and measured the length $(\mathrm{mm})$ and breadth $(\mathrm{mm})$ of all eggs with calipers. We calculated egg volume $\left(\mathrm{V}_{\mathrm{e}}\right)$ similar to Amat et al. (2001) using the equation

$$
\mathrm{V}_{\mathrm{e}}=\mathrm{K}_{\mathrm{v}} L W^{2},
$$

where $\mathrm{K}_{\mathrm{v}}$ corrects for variation in egg shape and is calculated by

$$
\mathrm{K}_{\mathrm{v}}=0.5236-[0.5236 * 2(\mathrm{~L} / \mathrm{W}) / 100],
$$

where $\mathrm{L}=$ egg length $(\mathrm{cm})$ and $\mathrm{W}=$ egg width $(\mathrm{cm})$.

To develop an index of habitat quality, during weekly surveys in 2008-2009, we recorded ocular estimates of percent dry ground, mud (areas wet from spring flow rather than rainwater), shallow water (1-5 cm deep; shallow enough for wading Snowy Plover), medium water $5-15 \mathrm{~cm}$ deep; too deep for wading Snowy Plover, but shallow enough for wading American Avocet [Recurvirostra americana]), and deep water $(>15 \mathrm{~cm}$ deep; too deep for wading American Avocet) to determine availability of surface water for nesting plovers throughout the breeding season. Specifically, during weekly surveys, we drew the locations of these 5 habitats on 2004 NAIP digital orthophoto quarter-quadrangle (DOQQ) aerial photographs (Texas Natural Resources Information System 2004) to estimate percent composition. To obtain total surface water availability, we summed percent mud, shallow water, medium water, and deep water for each survey.

\section{Capture and Handling}

We captured adult Snowy Plovers on nests using nest traps (Conway and Smith 2000) from early April to early August in 1999-2000 and 2008-2009. We banded all adults with a uniquely numbered U.S. Geological Survey aluminum band on the tibiotarsus and a unique combination of color bands on both right and left tarsometatarsi. Upon capture of each adult plover, we measured body mass ( $\mathrm{g}$ ) and the following morphological characteristics $(\mathrm{mm}$; see Pyle et al. 1987 for descriptions): flattened wing chord, tarsus, tail, culmen, bill depth, bill width, and head length. We measured mass to the nearest $0.1 \mathrm{~g}$ with a digital scale (Ohaus ${ }^{\circledR}$ Scout Pro Balance, Pine Brook, NJ). In addition, we collected a $50-\mu \mathrm{L}$ blood sample from each adult using brachial veinopuncture, stored the sample in lysis buffer, and then refrigerated it or kept it cool in coolers with ice packs while in the field (Longmire et al. 1997). In 1999-2000 and 2008-2009, we captured Snowy Plover chicks by hand in nests at hatching. We used the same handling and banding techniques for chicks as for adults, except that we collected a droplet of blood by puncturing the vein at the tibia-knee joint.

\section{Molecular Sexing}

We extracted DNA from blood stored in lysis buffer using the phenol-chloroform extraction techniques of Longmire et al. (1997). We performed polymerase chain reaction (PCR) following Conway et al. (2004), using CHD primer (Griffiths et al. 1996) P2-5'-TCT GCA TCG CTA AAT CCT TT-3' and labeled primer P8-6FAM-5'-CTC CCA AGG ATG AGR AAY TG-3' (Applied Biosystems, Foster City, CA). We amplified the CHD gene in $25-\mu \mathrm{L}$ reactions that consisted of 20-50 ng DNA, 2X PCR buffer, $0.8 \mathrm{mM}$ dNTPs (0.2 $\mathrm{mM}$ each), $2 \mathrm{mM} \mathrm{MgCl}_{2}, 0.3 \mu \mathrm{M}$ of each primer, and 0.02 $\mathrm{U}$ Taq polymerase. Thermocycler parameters 


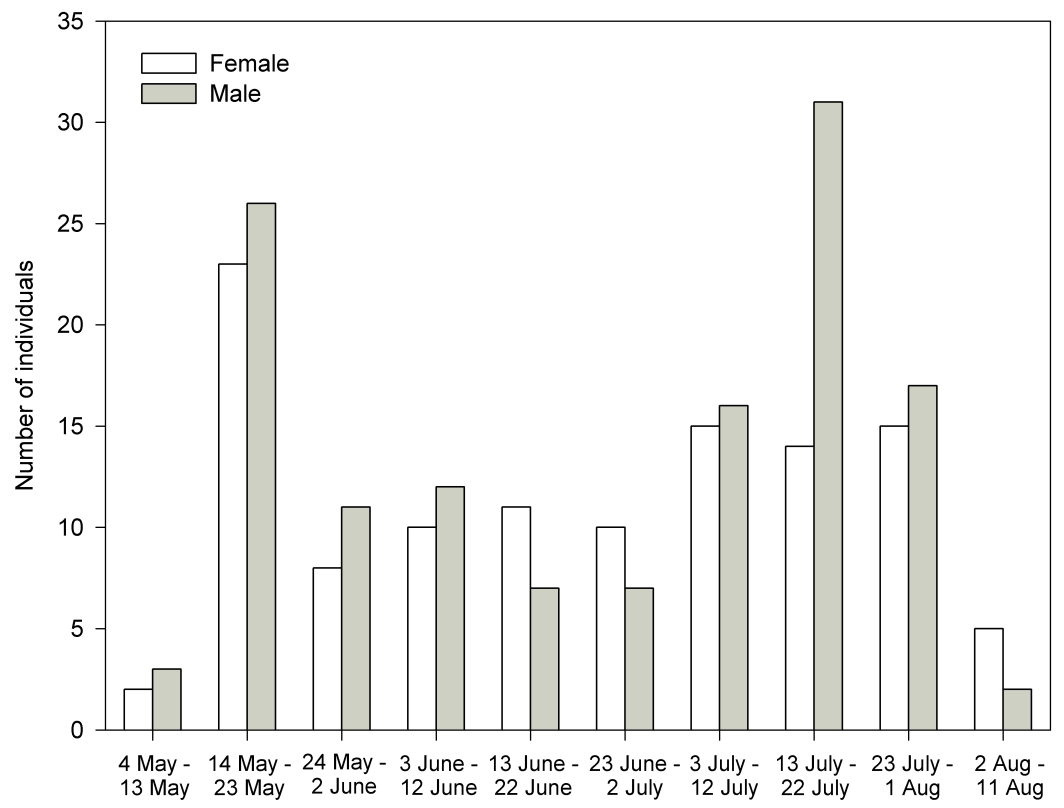

Fig. 1. Number of male and female Snowy Plover offspring captured within 10-day time periods on saline lakes within the Southern High Plains of Texas, USA, 1999-2000 and 2008-2009.

followed Conway et al. (2004) with an initial denature at $95{ }^{\circ} \mathrm{C}$ for $2 \mathrm{~min}$; followed by 36 cycles of denaturation at $95{ }^{\circ} \mathrm{C}$ for $1 \mathrm{~min}$, annealing at $45{ }^{\circ} \mathrm{C}$ for $1 \mathrm{~min}$, and $72{ }^{\circ} \mathrm{C}$ for 1 min; followed by a final extension at $72{ }^{\circ} \mathrm{C}$ for 2 min. We performed reactions on a 3100 Avant Genetic Analyzer (ABI) using $1 \mu \mathrm{L}$ of PCR product with a mixture of $0.5 \mu \mathrm{L}$ of Genescan-400HD ROX size standard (Applied Biosystems) and $12.5 \mu \mathrm{L}$ formamide. We visualized fragments using GeneMapper version 4.0 software (Applied Biosystems). To determine accuracy of the molecular sexing method, we retyped $9 \%$ of all samples (both adults and chicks).

\section{Statistical Analyses}

To determine if offspring sex ratios (total number of male chicks divided by total number of chicks) differed from parity within years (i.e., 1999, 2000, 2008, and 2009) and with years combined, we used a chi-square analysis (PROC FREQ; SAS Institute, Inc. 2002). To investigate seasonal differences in offspring sex ratios, we subdivided offspring into 10-day intervals (i.e., time periods) based on the range of hatching dates (i.e., 4 May-11 August), similar to Smallwood and Smallwood (1998). Because not all time periods had adequate sample sizes (see Fig. 1), we pooled time periods with samples sizes $<10$ individuals. This strategy resulted in the pooling of dates prior to 23 May and after 23 July for all years.

Because all chicks were not captured in the majority of clutches (i.e., failure to locate precocial chicks that left nest prior to capture), we were unable to use proportion of males within a clutch as the response variable. Rather, we modeled the probability a given individual was male by using a repeated-measures logistic regression. We examined variables influencing offspring sex by using generalized estimating equations (GEE) repeated among clutches, with binomial error and logit function (PROC GENMOD; SAS Institute, Inc. 2002). GEEs are an extension of generalized linear models that account for the covariance structure of response variables (Hardin and Hilbe 2003). We used the following explanatory variables to model sex of offspring: lake, year, linear time period trend (i.e., probability of producing a male within a time period [10-day interval periods] was linearly related to time), female body mass (sex of incubating parent was determined by molecular techniques), substrate type, mean egg volume of clutch, and percent surface water available during the week eggs were laid. Due to visual evidence of a nonlinear 
distribution of sex ratios (Fig. 1), we also evaluated a quadratic time period trend and a fourth-order polynomial time period trend as explanatory variables. Because there were missing covariate data for individuals (e.g., habitat data collected only in 2008-2009), the quasilikelihood criterion $\left(\mathrm{QIC}_{\mathrm{u}}\right.$; a modified version of Akaike's information criterion corrected for small sample size that can be used with GEEs) could not be used to rank models. Therefore, we evaluated models based on significance of explanatory variables, where parameter estimates, standard errors, and $P$ values are presented. To examine differences in offspring size between sexes, we examined differences in body measurements (i.e., tarsus length, wing chord length, and culmen length) and mass between male and female offspring using repeated-measures ANOVA repeated among clutches with a compound symmetric covariance structure (PROC MIXED; SAS Institute, Inc. 2002).

\section{RESUlTS}

We captured and sexed 245 chicks (45 in 1999, 87 in 2000, 38 in 2008, and 75 in 2009) from 118 clutches during the study. During all years, we retyped $9 \%$ of our samples (44 out of 502 individuals; 7 retyped once, 1 retyped twice, 19 retyped 3 times, and 17 retyped 4 times). For all retyped samples, our retyping accuracy rate was $100 \%$, with all retyped samples confirming the initial sex identification. Although offspring sex ratio was slightly malebiased $(53.8 \%)$ for the entire study, it did not deviate from parity $\left(\chi^{2}=1.47, \mathrm{df}=1, P=\right.$ 0.22 ). Additionally, offspring sex ratio did not deviate $(P>0.05)$ from parity within years, but was slightly male-biased in 1999, 2000, and $2009(1999=55.6 ; 2000=58.6 ; 2008=$ $44.7 ; 2009=52.0)$. Although not significant $\left(\chi^{2}=2.37, \mathrm{df}=1, P=0.12\right)$, for clutches in which all 3 chicks were captured $(n=36)$, offspring sex ratio was slightly male-biased $(57.4 \%)$, with few clutches $(n=9 ; 25 \%)$ producing only one sex ( 3 produced all females; 6 produced all males) and the majority producing combinations of both sexes (10 produced 1 male and 2 females; 17 produced 2 males and 1 female).

Among explanatory variables, the fourthorder polynomial time period trend and mean egg volume per clutch were significant $(P<$ 0.05 ; Table 1$)$, suggesting that the probability of producing male offspring was greater earlier and later in the season as compared to the middle of the season (Figs. 1, 2). Also, the probability of being male increased as mean clutch egg volume increased (Table 1). No other covariates influenced offspring sex ratios $(P>0.05$; Table 1$)$. Male offspring were generally larger than female offspring; however, this difference was significant only for tarsus length $(P<0.01$; Table 2$)$.

\section{Discussion}

Despite an odd modal clutch size, offspring sex ratios did not deviate from parity, suggesting an equal investment in males and females at a population level, despite sex-bias at the individual clutch scale. These results are consistent with a previous study on Kentish Plovers, where an unbiased offspring sex ratio was observed (46\%; Székely et al. 2004). However, unlike the previous study, a slightly malebiased offspring sex ratio was observed (54\%) in the SHP of Texas. Although the mating system and degree of female brood desertion is unknown within this population, several females did initiate second nesting attempts after their first nests hatched successfully ( $\mathrm{S}$. Saalfeld personal observation). This second attempt is possible only if females are able to find and acquire a new mate after their first nesting attempt (e.g., male-skewed adult sex ratio). However, the slight male-biased offspring sex ratio observed in this study is likely not significant enough to facilitate female-biased mating opportunities. Furthermore, slightly male-biased adult and juvenile apparent survival are likely not at levels high enough to facilitate female-biased mating opportunities (Saalfeld 2013), and no evidence exists of biased adult sex ratios within this population (Conway 2001). Therefore, any mechanism(s) facilitating female-biased mating opportunities in this population remains unknown.

Similar to a previous study on Kentish Plovers (Székely et al. 2004), offspring sex varied based on hatching date, suggesting benefits for females that seasonally adjust offspring sex ratios. However, unlike most previous studies on seasonal variation in sex ratios of birds, our observed offspring sex ratios did not follow simple linear trends, but rather, exhibited a bimodal distribution, with a greater proportion of males being produced both earlier and 
TABLE 1. Repeated-measures logistic regression models estimating probability of Snowy Plover offspring being male on saline lakes within the Southern High Plains of Texas, USA, 1999-2000 and 2008-2009.

\begin{tabular}{|c|c|c|c|c|c|}
\hline Model & Parameter & Estimate & SE & Z & $P$ \\
\hline \multirow[t]{3}{*}{ Lake $^{a}$} & Lake A & 0.10 & 0.17 & 0.59 & 0.55 \\
\hline & Lake B & 0.26 & 0.20 & 1.27 & 0.20 \\
\hline & Lake C & 0.18 & 0.60 & 0.30 & 0.76 \\
\hline \multirow[t]{4}{*}{ Yeara } & 1999 & 0.22 & 0.34 & 0.66 & 0.51 \\
\hline & 2000 & 0.35 & 0.22 & 1.57 & 0.12 \\
\hline & 2008 & -0.21 & 0.31 & -0.69 & 0.49 \\
\hline & 2009 & 0.08 & 0.22 & 0.36 & 0.72 \\
\hline \multirow{2}{*}{ Linear time period trend ${ }^{a}$} & Intercept & 0.07 & 0.29 & 0.26 & 0.80 \\
\hline & Time period & 0.02 & 0.05 & 0.33 & 0.74 \\
\hline \multirow[t]{3}{*}{ Quadratic time period trend ${ }^{a}$} & Intercept & 0.27 & 0.50 & 0.54 & 0.59 \\
\hline & Time period & -0.12 & 0.26 & -0.45 & 0.65 \\
\hline & $(\text { Time period })^{2}$ & 0.02 & 0.03 & 0.54 & 0.59 \\
\hline \multirow{5}{*}{ Fourth-order time period trenda } & Intercept & -2.74 & 1.66 & -1.65 & 0.10 \\
\hline & Time period & 4.74 & 2.27 & 2.09 & 0.04 \\
\hline & $(\text { Time period })^{2}$ & -2.24 & 0.96 & -2.34 & 0.02 \\
\hline & $(\text { Time period })^{3}$ & 0.39 & 0.16 & 2.48 & 0.01 \\
\hline & $(\text { Time period })^{4}$ & -0.02 & 0.01 & -2.55 & 0.01 \\
\hline \multirow[t]{2}{*}{ Female body mass ${ }^{b}$} & Intercept & -1.25 & 2.40 & -0.52 & 0.60 \\
\hline & Female body mass & 0.03 & 0.06 & 0.60 & 0.55 \\
\hline \multirow[t]{2}{*}{ Substrate } & Pebble & 0.12 & 0.19 & 0.64 & 0.53 \\
\hline & Sand & -0.38 & 0.40 & -0.94 & 0.35 \\
\hline \multirow[t]{2}{*}{ Mean egg volume ${ }^{c}$} & Intercept & -8.77 & 3.04 & -2.88 & $<0.01$ \\
\hline & Mean egg volume & 1.02 & 0.35 & 2.88 & $<0.01$ \\
\hline \multirow[t]{2}{*}{ Percent surface water availabilityd } & Intercept & 0.44 & 0.42 & 1.07 & 0.29 \\
\hline & Percent water & -0.01 & 0.01 & -1.05 & 0.29 \\
\hline
\end{tabular}

$\mathrm{a}_{n}=245$ chicks from 118 clutches.

$\mathrm{b}_{n}=157$ chicks from 78 clutches.

$c_{n}=113$ chicks from 59 clutches.

$\mathrm{d}_{n}=110$ chicks from 57 clutches.

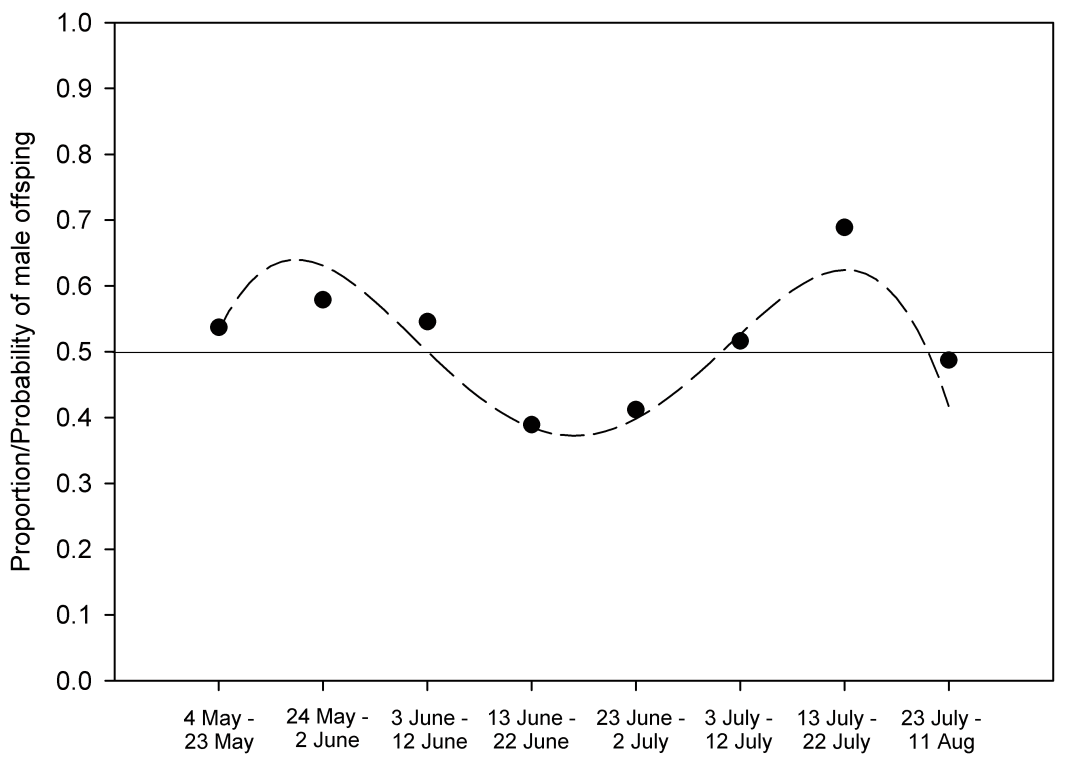

Fig. 2. Proportion of male Snowy Plover chicks captured within 10-day time periods and a fitted line from repeatedmeasures logistic regression (model $=$ fourth-order time period trend) estimating the probability of Snowy Plover offspring being male on saline lakes within the Southern High Plains of Texas, USA, 1999-2000 and 2008-2009. 
TABLE 2. Means $(\bar{x})$, standard errors (SE), least-squares (LS) estimates and SE, and $F$ and $P$ values resulting from repeated-measures ANOVA of Snowy Plover chick body measurements on saline lakes within the Southern High Plains of Texas, USA, 1999-2000 and 2008-2009.

\begin{tabular}{|c|c|c|c|c|c|c|}
\hline & \multicolumn{2}{|c|}{ Females $(n=112)$} & \multicolumn{2}{|c|}{ Males $(n=131)$} & \multirow[b]{2}{*}{$F$} & \multirow[b]{2}{*}{$P$} \\
\hline & $\bar{x}(\mathrm{LS})$ & SE (LS) & $\bar{x}(\mathrm{LS})$ & SE (LS) & & \\
\hline Body mass (g) & $5.85(5.88)$ & $0.08(0.08)$ & $5.93(5.92)$ & $0.08(0.08)$ & 0.15 & 0.70 \\
\hline Tarsus length (mm) & $17.68(17.63)$ & $0.20(0.21)$ & $17.71(17.98)$ & $0.20(0.21)$ & 8.86 & $<0.01$ \\
\hline Wing chord length (mm) & $11.00(11.02)$ & $0.09(0.10)$ & $11.18(11.20)$ & $0.09(0.09)$ & 2.13 & 0.15 \\
\hline Culmen length (mm) & $3.90(3.88)$ & $0.06(0.07)$ & $4.02(4.00)$ & $0.07(0.07)$ & 3.35 & 0.07 \\
\hline
\end{tabular}

later in the season. Although not observed in Kentish Plovers (Székely et al. 2004), this bimodal trend was apparent in Red-winged Blackbirds (Agelaius phoeniceus), where more males were produced in middle time periods when food abundance was likely to be greatest (Weatherhead 1983), and in American Kestrels (Falco sparverius), where more males were produced in both early and later time periods, although low sample size precluded statistical analysis (Smallwood and Smallwood 1998). We suggest that a bimodal pattern in offspring sex ratios in this Snowy Plover population may result from the unpredictability of the nesting environment that affords advantages to males hatching both early and late in the nesting season.

In the SHP of Texas, surface water and subsequent food availability on saline lakes vary unpredictably (within and between years) throughout the season, depending on unpredictable precipitation events. Within this region, saline lakes are discharge wetlands containing freshwater springs fed by the Ogallala aquifer that, at least historically, provided reliable surface water during the nesting season (Brune 2002). Despite historical reliability of surface water from these artesian springs, water levels and food availability now fluctuate more dramatically and unpredictably throughout the nesting season as availability of suitable habitat has become more reliant on unpredictable precipitation events than consistent spring flow. For example, earlier in the nesting season, when ambient temperatures and evapotranspiration rates are low, surface water levels and food availability are likely to be more predictable and reliable. As males are the more costly sex to produce (as indicated by tarsus length) and likely require additional energy input (as indicated by larger mean egg volume), more male offspring may be produced earlier in the season when food availability is likely to be greater. Although early hatching may benefit both sexes, fitness gains are potentially greater for males than females because Snowy Plovers exhibit male resource defense and both sexes attempt to breed within their first year (Warriner et al. 1986, Sandercock et al. 2005; W. Conway and S. Saalfeld personal observation). Individuals born earlier have more time to acquire food prior to migration, a fitness advantage that may carry over into the following breeding season(s) (Andersson et al. 2003). Because male Snowy Plovers compete for and defend nesting territories, there are likely differences in breeding success between the sexes, although estimates of actual fitness gains by males born earlier in the season remain unknown (Székely et al. 2004).

As the nesting season progresses, temperatures and evapotranspiration rates increase, resulting in more ephemeral and unpredictable surface water presence, with the maintenance of surface water dependent on unpredictable precipitation events. As the amount of surface water present on saline lakes in the SHP of Texas determines salinity levels and invertebrate community composition (with arthropod biomass decreasing exponentially when salinity increases above $40 \mathrm{~g} \cdot \mathrm{L}^{-1}$; Andrei et al. 2008), fluctuating water levels may result in inconsistent and unpredictable food availability. Therefore, sex ratio adjustment in this environment may not be straightforward and may follow nonlinear models and/or vary annually in response to environmental conditions (i.e., habitat quality). Alternatively, offspring sex ratios in this population of Snowy Plovers may follow unpredictable surface water patterns, where more male offspring are produced when perceived food availability is greater, regardless of time during a given nesting season. For example, nests initiated following a severe weather event late in the season in 1999 (that greatly increased surface water availability in 
June) produced more male offspring (S. Saalfeld unpublished).

Producing male offspring late in the season may also have selective advantages. Because males have faster growth rates than females (Székely et al. 2004), and may fledge earlier, producing males late in the season may allow the care-giving parent(s) to migrate earlier or focus on acquiring food prior to migration. Therefore, production of males late in the season could provide fitness and survival benefits for the care-giving parent(s). Although the mating system and degree of female brood desertion is unknown within this population, if males are the sole care-giving adult in this population, selective advantages of producing males late in the season may not exist for females. However, if both sexes provide care to chicks, producing males late in the season may provide selective advantages for both parents. Late-born chicks may also have survival advantages over early born chicks. For example, the majority of male offspring (i.e., 15 out of 16) returning the following nesting season were born late in the season (i.e., after 3 July; S. Saalfeld unpublished). Although chick survival (from hatching to fledging) was not determined in this study, late hatching could result in greater chick survival if fewer devastating weather events occur later in the season (Colwell et al. 2007), greater surface water is available (although unpredictable and variable from year to year), predation rates are lower due to other species being present (e.g., migrant sandpipers; Colwell et al. 2007), and/ or late-born individuals migrate shorter distances or remain with wintering flocks (although all individuals nesting in the SHP of Texas are solely migratory; Colwell et al. 2007). However, these potential factors influencing seasonal survival rates may vary annually and spatially and provide inconsistent advantages to chicks born at specific times.

Despite our suggestion that the bimodal pattern in offspring sex ratios observed in this population may be the result of the unpredictability of the nesting environment, we were unable to document a relationship between offspring sex ratio and a measure of habitat quality (i.e., percent surface water availability during the week eggs were laid). The inability to detect a significant relationship between the 2 variables, however, could be due to a lack of data for 2 out of the 4 years of this study or our inability to measure the proximal cue for sex determination in this species. For example, sex ratio adjustment may be based on perceived food availability that is independent of surface water levels during the week eggs are laid. Alternatively, there may be a time lag between sex determination and egg production, resulting in different surface water levels present when eggs are laid than when sex determination occurs. Therefore, future research should focus on determining and measuring the proximal cues for offspring sex ratio adjustment in this population.

Within the SHP of Texas, Snowy Plover populations have declined within the past 10 years (Saalfeld et al. 2013), clearly highlighting the need for regional conservation efforts. For conservation to be successful, understanding the current dynamics influencing population growth, such as population size, mortality rates, recruitment rates, and sex ratios, remains important. This population appears to have seasonal shifts in offspring sex ratios, and these shifts may be related to female condition as well as to differential advantages of sexes being born at specific times. Currently, the mechanism for seasonal variation in sex ratios remains unknown (Krackow 1995, Pike and Petrie 2003, Alonso-Alvarez 2006), as well as the effects such changes may have on population growth and stability. One of the primary conservation concerns within this region is surface water availability in saline lakes (Saalfeld 2010), where declining spring flow due to decreasing water table levels of the aquifer has occurred since the 1950s (Brune 2002). This decline, which has been driven by groundwater pumping for row-crop irrigation in the most intensively agriculturalized regions in North America (Bolen et al. 1989), has shortened saline lake hydroperiods and increased surface water salinity. Because freshwater springs not only provide reliable surface water during the breeding season, a necessary landscape feature for nesting Snowy Plovers (Conway et al. 2005b), but also support salt-intolerant invertebrate prey (Andrei et al. 2009), declining spring flow may decrease suitability of saline lakes for nesting shorebirds, as well as decrease food availability during the nesting season, resulting in poor condition of nesting individuals. Long-term reduction in food availability and subsequent poor condition of nesting females may result in significant changes in 
offspring sex ratios (Cooch et al. 1997). Because females in poor condition are likely to produce more females (Trivers and Willard 1973), if conditions continue to decline within this region, sex ratios may become more female-biased, having potentially dramatic effects on population growth and stability. Therefore, it remains important to provide high-quality habitat for nesting Snowy Plovers in the SHP of Texas. As surface water availability is the main factor influencing regional saline lake habitat quality, conserving the Ogallala aquifer and associated freshwater artesian springs discharging into saline lakes will stand to improve surface water availability and habitat quality. However, because the Ogallala aquifer is recharged from playa wetlands (Osterkamp and Wood 1987, Bolen et al. 1989), it also remains important to conserve the entire complex of wetlands within the SHP of Texas (Andrei et al. 2008, 2009).

\section{ACKNOWLEDGMENTS}

Financial, logistical, and technical support provided in part by the Texas Parks and Wildlife Department, Arthur Temple College of Forestry and Agriculture, Stephen F. Austin State University, the Department of Natural Resources Management, Texas Tech University, and U.S. Fish and Wildlife Service. Thanks to J. Neal, D. Saalfeld, M. Buckingham, R. Baker, and M. McDonough and all others who assisted with field and laboratory work. We thank B. Burt, C. Comer, and D. Scognamillo for comments and reviews on previous versions of this manuscript. Finally, we thank the landowners for allowing access to saline lakes located on their properties.

\section{Literature Cited}

Alonso-Alvarez, C. 2006. Manipulation of primary sexratio: an updated review. Avian and Poultry Biology Reviews 17:1-20.

Amat, J.A., R.M. Fraga, and G.M. Arroyo. 1999. Brood desertion and polygamous breeding in the Kentish Plover Charadrius alexandrinus. Ibis 141:596-607.

2001. Intraclutch egg-size variation and offspring survival in the Kentish Plover Charadrius alexandrinus. Ibis 143:17-23.

Andersson, M., J. Wallander, L. Oring, E. Akst, J.M. REED, AND R.C. Fleischer. 2003. Adaptive seasonal trend in brood sex ratio: test in two sister species with contrasting breeding systems. Journal of Evolutionary Biology 16:510-515.

Andrei, A.E., L.M. Smith, D.A. Haukos, and J.G. SuRLES. 2008. Habitat use by migrant shorebirds in saline lakes of the Southern Great Plains. Journal of Wildlife Management 72:246-253.

Andrei, A.E., L.M. Smith, D.A. Haukos, J.G. Surles, and W.P. Johnson. 2009. Foraging ecology of migrant shorebirds in saline lakes of the Southern Great Plains. Waterbirds 32:138-148.

AnKNey, C.D. 1982. Sex ratio varies with egg sequence in Lesser Snow Geese. Auk 99:662-666.

BednaRZ, J.C., ANd T.J. Hayden. 1991. Skewed brood sex ratio and sex-biased hatching sequence in Harris's Hawks. American Naturalist 137:116-123.

BLANK, J.L., AND V. NOLAN JR. 1983. Offspring sex ratio in Red-winged Blackbirds is dependent on maternal age. Proceedings of the National Academy of Sciences 80:6141-6145.

Bolen, E.G., L.M. Smith, and H.L. Schramm JR. 1989. Playa lakes: prairie wetlands of the Southern High Plains. BioScience 39:615-623.

BoyD, R.L. 1972. Breeding biology of the Snowy Plover at Cheyenne Bottoms Waterfowl Management Area, Barton County, Kansas. Master's thesis, Kansas State Teachers College, Emporia, KS.

Brune, G.M. 2002. Springs of Texas. Volume 1. Texas A\&M University Press, College Station, TX.

Burley, N. 1981. Sex ratio manipulation and selection for attractiveness. Science 211:721-722.

Byholm, P., J.E. Brommer, and P. Saurola. 2002. Scale and seasonal sex-ratio trends in Northern Goshawk Accipiter gentilis broods. Journal of Avian Biology 33: 399-406.

Clutton-Brock, T.H. 1986. Sex ratio variation in birds. Ibis $128: 317-329$.

Colwell, M.A., S.J. Hurley, J.N. Hall, and S.J. DinsMORE. 2007. Age-related survival and behavior of Snowy Plover chicks. Condor 109:638-647.

Conway, W.C. 2001. Breeding ecology of shorebirds in the Playa Lakes region of Texas. Doctoral dissertation, Texas Tech University, Lubbock, TX.

Conway, W.C., And L.M. Smith. 2000. A nest trap for Snowy Plovers. North American Bird Bander 25: $45-47$.

Conway, W.C., L.M. Smith, and J.D. RaY. 2005a. Shorebird breeding biology in wetlands of the Playa Lakes, Texas, USA. Waterbirds 28:129-138. 2005b. Shorebird habitat use and nest-site selection in the Playa Lakes Region. Journal of Wildlife Management 69:174-184.

Conway, W.C., J.K. Wickliffe, F.G. Hoffmann, R.J. BAKER, AND L.M. SMITH. 2004. An improved PCRbased method for gender identification in birds. Occasional Papers of the Museum of Texas Tech University $239: 1-7$.

Cooch, E., D. Lank, R. Robertson, and F. Cooke. 1997. Effects of parental age and environmental change on offspring sex ratio in a precocial bird. Journal of Animal Ecology 66:189-202.

Cordero, P.J., J. Viñuela, J.M. Aparicio, and J.P. Veiga. 2001. Seasonal variation in sex ratio and sexual egg dimorphism favouring daughters in first clutches of the Spotless Starling. Journal of Evolutionary Biology 14:829-834.

Daan, S., C. Dijkstra, and F.J. Weissing. 1996. An evolutionary explanation for seasonal trends in avian sex ratios. Behavioral Ecology 7:426-430.

Dijkstra, C., S. DaAn, And J.B. Buker. 1990. Adaptive seasonal variation in the sex ratio of kestrel broods. Functional Ecology 4:143-147. 
Ellegren, H., L. Gustafsson, and B.C. Sheldon. 1996. Sex ratio adjustment in relation to parental attractiveness in a wild bird population. Proceedings of the National Academy of Sciences 93:11723-11728.

Ellegren, H., ANd B.C. Sheldon. 1997. New tools for sex identification and the study of sex allocation in birds. Trends in Ecology and Evolution 12:255-259.

Fisher, R. 1930. The genetical theory of natural selection. Oxford University Press, Oxford.

Gowatr, P.A. 1993. Differential dispersal, local resource competition, and sex ratio variation in birds. American Naturalist 141:263-280.

Griffiths, R., S. DaAn, and C. Dijkstra. 1996. Sex identification in birds using two CHD genes. Proceedings of the Royal Society of London Series B 263: $1251-1256$.

Griffiths, R., M.C. Double, K. Orr, and R.J.G. DawSON. 1998. A DNA test to sex most birds. Molecular Ecology 7:1071-1075.

Griggio, M., F. Hamerstrom, R.N. Rosenfield, and G. TAVECCHIA. 2002. Seasonal variation in sex ratio of fledgling American Kestrels: a long term study. Wilson Bulletin 114:474-478.

Hardin, J.W., and J.M. HilBe. 2003. Generalized estimating equations. Chapman and Hall/CRC, Boca Raton, FL.

Howe, H.F. 1977. Sex-ratio adjustment in the Common Grackle. Science 198:744-746.

Korpimäki, E., C.A. MaY, D.T. Parkin, J.H. Wetton, and J. WIEHN. 2000. Environmental- and parental condition-related variation in sex ratio of kestrel broods. Journal of Avian Biology 31:128-134.

KraCKOW, S. 1995. Potential mechanisms for sex ratio adjustment in mammals and birds. Biological Reviews 70:225-241.

Küpper, C., J. Kis, A. Kosztolányi, T. Székely, I.C. Cuthill, and D. BlomQvist. 2004. Genetic mating system and timing of extra-pair fertilizations in the Kentish Plover. Behavioral Ecology and Sociobiology 57:32-39.

LEsseLLS, C.M. 1984. The mating system of Kentish Plovers Charadrius alexandrinus. Ibis 126:474-483.

Longmire, J.L., M. Maltbie, and R.J. Baker. 1997. Use of "lysis buffer" in DNA isolation and its implication for museum collections. Occasional Papers of the Museum of Texas Tech University 163:1-3.

McIntosh, R.R., R. Kats, M. Berg, J. Komdeur, and M.A. Elgar. 2003. Breeding ecology and bias in offspring sex ratio in Little Grassbirds (Megalurus gramineus). Australian Journal of Zoology 51:505-514.

Mead, P.S., M.L. Morton, and B.E. Fish. 1987. Sexual dimorphism in egg size and implications regarding facultative manipulation of sex in Mountain Whitecrowned Sparrows. Condor 89:798-803.

Myers, J.H. 1978. Sex ratio adjustment under food stress: maximization of quality or numbers of offspring? American Naturalist 112:381-388.

Nager, R.G., P. Monaghan, R. Griffiths, D.C. HousTON, AND R. DAWSON. 1999. Experimental demonstration that offspring sex ratio varies with maternal condition. Proceedings of the National Academy of Sciences 96:570-573.

Olsen, P.D., And A. Cockburn. 1991. Female-biased sex allocation in Peregrine Falcons and other raptors. Behavioral Ecology and Sociobiology 28:417-423.

OsterkamP, W.R., AND W.W. WoOD. 1987. Playa-lake basins on the Southern High Plains of Texas and New Mexico: Part I. Hydrologic, geomorphic, and geologic evidence for their development. Geological Society of America Bulletin 99:215-223.

Page, G.W., L.E. Stenzel, G.W. Page, J.S. Warriner, J.C. Warriner, and P.W. Paton. 2009. Snowy Plover (Charadrius alexandrinus). In: A. Poole, editor, The birds of North America online. Cornell Lab of Ornithology, Ithaca, NY. Available from: http://bna.birds. cornell.edu/bna/species/154

Pen, I., F.J. Weissing, and S. Daan. 1999. Seasonal sex ratio trend in the European Kestrel: an evolutionarily stable strategy analysis. American Naturalist 153: 384-397.

Pike, T.W., AND M. Petrie. 2003. Potential mechanisms of avian sex manipulation. Biological Reviews 78: 553-574.

Pyle, P., S.N.G. Howell, R.P. Yunick, and D.F. DeSANTE. 1987. Identification guide to North American passerines. Slate Creek Press, Bolinas, CA.

Reeves, C.C., Jr., and J.M. Temple. 1986. Permian salt dissolution, alkaline lake basins, and nuclear-waste storage, Southern High Plains, Texas and New Mexico. Geology 14:939-942.

SAALFELD, S.T. 2010. Snowy Plover population and breeding ecology in saline lakes of the Southern High Plains of Texas. Doctoral dissertation, Stephen F. Austin State University, Nacogdoches, TX.

SaAlfeld, S.T., W.C. Conway, D.A. Haukos, and W.P. JoHnson. 2013. Recent declines in apparent survival and survey counts of Snowy Plovers breeding in the Southern High Plains of Texas. Wilson Journal of Ornithology 125:79-87.

SANDERCOCK, B.K., T. SZÉKely, and A. KosztolánYi. 2005. The effects of age and sex on the apparent survival of Kentish Plovers breeding in southern Turkey. Condor 107:583-596.

SAS InSTITUTE, InC. 2002. SAS/STAT software, version 9. SAS Institute, Inc., Cary, NC.

Sheldon, B.C., S. Andersson, S.C. Griffith, J. ÖrnBORG, AND J. SENDECKA. 1999. Ultraviolet colour variation influences Blue Tit sex ratios. Nature 402: 874-877.

SmallwoOd, P.D., and J.A. Smallwood. 1998. Seasonal shifts in sex ratios of fledgling American Kestrels (Falco sparverius paulus): the early bird hypothesis. Evolutionary Ecology 12:839-853.

Stenzel, L.E., G.W. Page, J.C. Warriner, J.S. WarRiner, K.K. Neuman, D.E. George, C.R. Eyster, And F.C. Bidstrup. 2011. Male-skewed adult sex ratio, survival, mating opportunity and annual productivity in the Snowy Plover Charadrius alexandrinus. Ibis 153:312-322.

SzÉKELY, T., AND I.C. CUTHILl. 1999. Brood desertion in Kentish Plover: the value of parental care. Behavioral Ecology 10:191-197.

. 2000. Trade-off between mating opportunities and parental care: brood desertion by female Kentish Plovers. Proceedings of the Royal Society of London Series B 267:2087-2092.

SzÉKEly, T., I.C. CUThill, AND J. Kis. 1999. Brood desertion in Kentish Plover: sex differences in remating opportunities. Behavioral Ecology 10:185-190.

Székely, T., I.C. Cuthill, S. Yezerinac, R. Griffiths, AND J. KIs. 2004. Brood sex ratio in the Kentish Plover. Behavioral Ecology 15:58-62.

Székely, T., AND C.M. Lessells. 1993. Mate change by Kentish Plovers Charadrius alexandrinus. Ornis Scandinavica 24:317-322. 
SzÉkely, T., AND T.D. WiLliams. 1994. Factors affecting timing of brood desertion by female Kentish Plovers Charadrius alexandrinus. Behaviour 130:17-28.

1995. Costs and benefits of brood desertion in female Kentish Plovers, Charadrius alexandrinus. Behavioral Ecology and Sociobiology 37:155-161.

Tella, J.L., J.A. Donazar, J.J. Negro, and F. Hiraldo. 1996. Seasonal and interannual variations in the sexratio of Lesser Kestrel Falco naumanni broods. Ibis 138:342-345.

Texas Natural Resources Information System. 2004. Available from: http://www.tnris.state.tx.us/.

Trivers, R.L., AND D.E. Willard. 1973. Natural selection of parental ability to vary the sex ratio of offspring. Science 179:90-92.

[USFWS] United States Fish and Wildlife Service. 1993. Endangered and threatened wildlife and plants; determination of threatened status for the Pacific Coast population of the Western Snowy Plover. Federal Register 58:12864-12874.
Warriner, J.S., J.C. Warriner, G.W. Page, and L.E. STENZEL. 1986. Mating system and reproductive success of a small population of polygamous Snowy Plovers. Wilson Bulletin 98:15-37.

Weatherhead, P.J. 1983. Secondary sex ratio adjustment in Red-winged Blackbirds (Agelaius phoeniceus). Behavioral Ecology and Sociobiology 12:57-61.

Wiebe, K.L., AND G.R. BortolotTi. 1992. Facultative sex ratio manipulation in American Kestrels. Behavioral Ecology and Sociobiology 30:379-386.

Zijlstra, M., S. DaAn, and J. BruinenberG-Rinsma. 1992. Seasonal variation in the sex ratio of Marsh Harrier Circus aeruginosus broods. Functional Ecology 6: 553-559.

Received 10 February 2012 Accepted 26 October 2012 